\title{
Differences among Shigella spp. in Susceptibility to the Bactericidal Activity of Human Serum
}

\author{
By NOBORU OKAMURA, ${ }^{1}$ * RINTARO NAKAYA, ${ }^{2}$ KENJI SUZUKI, ${ }^{3}$ \\ SEIICHI KONDO, ${ }^{4}$ KAZUHITO HISATSUNE, ${ }^{4}$ \\ YATSUKA IMAGAWA, ${ }^{5}$ HIROKO SAGARA ${ }^{6}$ AND \\ YOSHIO MATSUBARA 6 \\ ${ }^{1}$ Department of Microbiology, The Institute of Public Health, Shirokanedai, Minato-ku, \\ Tokyo 108, Japan \\ ${ }^{2}$ Department of Microbiology, Tokyo Medical and Dental University School of Medicine, \\ Bunkyo-ku, Tokyo 113, Japan \\ ${ }^{3}$ Department of Technology, National Institute of Health, Shinagawa-ku, Tokyo 141, Japan \\ ${ }^{4}$ Department of Microbiology, School of Pharmaceutical Sciences, Josai University, Sakado, \\ Saitama 350-02, Japan \\ ${ }^{5}$ Tokyo Metropolitan Bokuto General Hospital, Sumida-ku, Tokyo 130, Japan \\ ${ }^{6}$ Tokyo Metropolitan Toshima General Hospital, Itabashi-ku, Tokyo 173, Japan
}

(Received 5 January 1988)

\begin{abstract}
Clinical isolates of Shigella spp. were examined for their susceptibility to human serum. The susceptibility of the strains to immune and nonimmune human serum was dependent upon the size of the bacterial inoculum and the concentration of serum. There were differences among Shigella spp. in susceptibility to human serum: $S$. sonnei strains were the least susceptible, strains of $S$. boydii and $S$. flexneri serotype 6 were intermediate, and those of $S$. flexneri other than serotype 6 and $S$. dysenteriae were the most susceptible. Experiments in which heat-treated $\left(56{ }^{\circ} \mathrm{C}\right.$ for $30 \mathrm{~min}$, or $50{ }^{\circ} \mathrm{C}$ for $20 \mathrm{~min}$ ) serum was used, and analysis of activation of complement by lipopolysaccharides (LPS) from each Shigella sp., suggested that LPS composition, especially the $O$ antigen polysaccharide chains, contributes to the differences among Shigella spp. in susceptibility to human serum.
\end{abstract}

\section{INTRODUCTION}

Diarrhoeal disease is a major cause of morbidity and mortality worldwide, especially in developing countries. Shigella is one of the most important causes of diarrhoeal disease (Blaser $e t$ al., 1983; DuPont \& Pickering, 1980; Stoll et al., 1982). Shigellosis is caused by invasion of the epithelium and subsequent multiplication in the gut cells by virulent Shigella organisms, resulting in a massive inflammatory response in the gut mucosa (Keusch, 1979; LaBrec et al., 1964; Ogawa et al., 1967; Okamura et al., 1983). Although Shigella rarely invades the blood stream and causes generalized infection (Keusch, 1979), several studies suggest that Shigella bacteraemia may occur more frequently, and may bear a high case fatality rate, in the immunocompromised host (Hallet \& Scragg, 1978; Koshi et al., 1979; Struelens et al., 1985). Shigellosis due to $S$. sonnei is becoming more common (Blaser et al., 1983; Parker, 1984) than shigellosis due to other Shigella spp., especially in the industrialized countries.

The mechanism of immunity against Shigella spp. remains unclear. There have been several reports on the role of host defence factors (polymorphonuclear leucocytes, macrophages, lymphocytes, antibodies and complement) in the pathogenesis of shigellosis (Lowell et al., 1980;

Abbreviation: $\mathrm{GVB}^{2+}$, gelatin/veronal buffer supplemented with $\mathrm{Ca}^{2+}$ and $\mathrm{Mg}^{2+}$ 
Morgan et al., 1984a, b; Reed, 1975, Reed \& Albright, 1974). Human serum provides the host with antibodies and complement, both or either of which act as opsonins and facilitate killing by polymorphonuclear leucocytes. Complement also has bactericidal activity through the classical and alternative pathways, with or without the need for specific antibodies (Taylor, 1983). Fresh serum is capable of killing certain strains of Shigella. Wardlaw \& Pillemer (1956) studied this bactericidal system using $S$. dysenteriae 1 strain and attributed it to the properdin system. Reed \& Albright (1974) reported that there was a wide range of susceptibility among strains of Shigella, and that there was little difference in killing activity between individual sera and no relationship between antibody titres and killing capacity.

In the work described here, we determined the susceptibility of 174 Shigella strains to normal human serum. For five representative strains we studied the effect of serum concentration and size of bacterial inoculum on serum killing, and investigated the involvement of complement and bacterial LPS.

\section{METHODS}

Bacterial strains. Strains of $S$. dysenteriae (13 strains, serotypes 1, 2, 3, 4 and 8), S. flexneri (94 strains, including all serotypes), $S$. boydii (9 strains, serotypes 1, 3, 4, 5 and 10), and $S$. sonnei (58 strains, including both form I and form II) were isolated from patients with dysentery at various hospitals in metropolitan Tokyo and the Yokohama and Osaka areas. The following were used as representative strains for more detailed studies of serum bactericidal activity; S. dysenteriae 2 M8, S. flexneri 2a T4, S. flexneri 6 M7, S. boydii 4 SH71, S. sonnei M23. Serotypes were always confirmed by agglutination test using specific antisera (Denka-Seiken Co.) prior to each experiment.

Sera. Pooled normal human serum was obtained from several laboratory volunteers who denied previous Shigella infection. To minimize potential differences in the bactericidal activity of normal human serum among donors, most of the experiments were done with a single pool of serum containing about $36-37 \mathrm{CH}_{50}$ units ml-1 of haemolytic complement components. Normal individual sera and sera from patients with Shigella dysentery were also used and compared with each other to see if there were any differences in bactericidal activity among donors. Human serum was stored at $-80^{\circ} \mathrm{C}$ in $1 \mathrm{ml}$ samples and was discarded after being thawed once.

Treatment of sera. Sera were treated with heat or chelator to examine the role of serum complement. Classical pathway activity of complement in pooled normal human serum was selectively inhibited by chelation with $0.2 \mathrm{M}$ EGTA (Sigma), $\mathrm{pH} 7 \cdot 5$, at a final concentration of 10 or $20 \mathrm{mM}$, with 2 or $5 \mathrm{mM}-\mathrm{MgCl}_{2}$ (Fine et al., 1972). Alternative pathway activity of complement was selectively inactivated by heat treatment $\left(50^{\circ} \mathrm{C}, 20 \mathrm{~min}\right)$. Both classical and alternative pathway activities were inhibited by heat at $56^{\circ} \mathrm{C}$ for $30 \mathrm{~min}$.

Preparation of lipopolysaccharides (LPS). LPS were isolated from acetone-dried cells by the phenol/water method of Westphal et al. (1952) and purified by repeated ultracentrifugation $(105000 \mathrm{~g})$ and treatment with RNAase ( $20 \mu \mathrm{g} \mathrm{ml}^{-1}$ in $25 \mathrm{mM}$-Tris/HCl buffer, $\left.\mathrm{pH} 7.4\right)$ (Okamura et al., 1983).

Haemolytic complement assay. The total haemolytic complement activity, expressed as the amount of complement required to lyse $50 \%$ of sensitized sheep erythrocytes $\left(\mathrm{CH}_{50}\right)$, was measured according to the method of Mayer (1961) with a slight modification.

Serum bactericidal assay. A qualitative assay was first done to examine the susceptibility of all the Shigella strains to the bactericidal activity of pooled normal human serum. Exponential-phase cultures were inoculated into tryptone/glucose broth $[0.5 \%$ tryptone (Difco), $0.5 \%$ glucose, $0.5 \% \mathrm{NaCl}, \mathrm{pH} 7.4]$ containing $10 \%(\mathrm{v} / \mathrm{v})$ normal human serum as described by Moll et al. (1979), to give $10^{6}-10^{7}$ cells $\mathrm{ml}^{-1}$. Bromothymol blue was added to the cultures as a pH indicator. The cultures were then incubated at $37^{\circ} \mathrm{C}$ for $6-7 \mathrm{~h}$ and overnight. If the bacteria are killed, the medium remains green, whereas if they survive and grow, the medium turns yellow.

Quantitative serum bactericidal assays were done as follows, using microtitre plates. Ten-microlitre portions of exponential-phase cultures of Shigella were inoculated into $0.2 \mathrm{ml}$ of serum dilutions in tryptone/glucose broth, Hanks' solution, or gelatin/veronal buffer supplemented with $\mathrm{Ca}^{2+}$ and $\mathrm{Mg}^{2+}\left(\mathrm{GVB}^{2+}\right)$, and incubated at $37^{\circ} \mathrm{C}$. Viable counts of bacteria were done at appropriate intervals by the duplicate plate method using Trypticase soy agar (BBL).

Measurement of anticomplementary activity of Shigella LPS. The anticomplementary activity of LPS was measured as described by Shafer $e$ t al. (1984), with slight modifications. Serum was mixed with LPS (0.063-1 mg) suspended in $\mathrm{GVB}^{2+}$ in a final volume of $0.2 \mathrm{ml}$ and incubated with shaking at $37^{\circ} \mathrm{C}$ for $2 \mathrm{~h}$. Antibody-sensitized sheep erythrocytes in $\mathbf{0 . 2} \mathrm{ml} \mathrm{GVB}^{2+}$ were added to a fourfold dilution of the treated serum and incubated for an additional $30 \mathrm{~min}$ in a $37^{\circ} \mathrm{C}$ water bath. Ice-cold $0.85 \%$ saline $(3 \mathrm{ml})$ was added to the mixture, the cells were pelleted by centrifugation $(800 \mathrm{~g}, 5 \mathrm{~min})$, and the absorbance of the supernatant was measured at $412 \mathrm{~nm}$. The positive control was sensitized erythrocytes plus serum without added LPS, and the negative control was LPS plus erythrocytes without added serum. 
Inhibition of serum bactericidal activity by Shigella LPS. Shigella LPS was suspended in distilled water to a final concentration of $2 \mathrm{mg} \mathrm{ml}^{-1}$ and sonicated until the suspension cleared. LPS solution in the concentration range $0.05-1 \mathrm{mg} \mathrm{ml}^{-1}$ was added to $0.2 \mathrm{ml}$ serum in a well of a microtitre plate. The solution was incubated at $37^{\circ} \mathrm{C}$ for

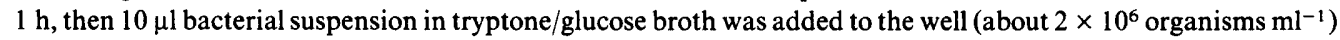
and incubated at $37^{\circ} \mathrm{C}$ for an additional $2 \mathrm{~h}$ before dilution plating.

Reproducibility of results. All the experiments reported were done at least twice. The results shown are from representative experiments.

\section{RESULTS}

\section{Serum bactericidal activity}

We first examined the 174 strains of Shigella for their susceptibility to $10 \%$ pooled normal human serum by the qualitative test. Almost all of the $S$. sonnei form I and six of the nine $S$. boydii strains grew in this reaction mixture. Six of the $11 S$. flexneri 6 strains were not susceptible. $S$. flexneri strains other than serotype 6, and all the strains of $S$. dysenteriae, were susceptible. Strains of $S$. sonnei which were susceptible to normal human serum were all form II strains.

We then chose a representative strain from each species and from $S$. flexneri 6 . These strains were examined for susceptibility to pooled normal human serum by doing viable counts at appropriate times. A serum concentration of $10 \%$ in tryptone/glucose broth and a bacterial inoculum of $10^{6}$ organisms $\mathrm{ml}^{-1}$ were first chosen. Fig. 1 shows the time course of the serum bactericidal assay. The $S$. flexneri $2 \mathrm{a}$ and $S$. dysenteriae 2 strains were killed rapidly, with a more than 1000 -fold reduction in viable counts within $2 \mathrm{~h}$. No decrease in viable counts was observed with the $S$. sonnei form I strain. The $S$. flexneri 6 and $S$. boydii 4 strains showed a slight decrease in viable counts at $2 \mathrm{~h}$ after inoculation, but kept growing thereafter (Fig. 1). These results were in agreement with those of the qualitative tests mentioned above. There were no differences in growth rate among the representative strains of Shigella (results not shown). We also examined the serum bactericidal activity with $\mathrm{GBV}^{2+}$ or Hanks' solution as serum diluent, and obtained similar results to those with tryptone/glucose broth. However, better reproducibility and higher killing potency were achieved with tryptone/glucose broth as serum diluent, and this diluent was therefore used for most of the experiments unless stated otherwise. Exponential-phase bacteria were more susceptible to serum killing than were stationary-phase bacteria (data not shown).

The bactericidal capacity of pooled normal human serum at different concentrations was examined (Table 1). S. flexneri 6 and S. boydii strains were killed at a serum concentration of $20 \%$, whereas none of the $S$. sonnei strains examined were susceptible at this concentration. As the concentration of serum was increased to $80 \%$, the number of susceptible $S$. sonnei strains increased, but some strains remained resistant.

We then examined the killing effect of $10 \%$ human serum with various concentrations of bacterial inoculum. As the inoculum of bacteria increased, even the $S$. dysenteriae 2 and $S$. flexneri 2a strains became less susceptible to the serum killing (Fig. 2). On the other hand, even the $S$. sonnei M23 strain was killed efficiently when the inoculum was $10^{4}$ organisms ml-1 (not shown). Moreover, all of the 32 wild-type strains of $S$. sonnei form I tested were susceptible to $10 \%$ human serum with such an inoculum.

\section{Bactericidal activity of individual sera and sera from dysentery patients}

The killing efficacy of individual human sera was examined to see if there were differences in serum bactericidal activity among donors. Four serum specimens from normal human volunteers and 24 serum specimens from dysentery patients (causative organisms: $S$. sonnei, 15 patients; $S$. flexneri, 7 patients; $S$. boydii, 2 patients) were examined. The total haemolytic complement activity of these sera ranged from 27 to $48 \mathrm{CH}_{50}$ units $\mathrm{ml}^{-1}$. The representative Shigella strains mentioned above were inoculated into $10 \%$ human serum in tryptone/glucose broth and viable bacteria were counted after $2 \mathrm{~h}$ incubation at $37^{\circ} \mathrm{C}$. Despite slight fluctuation with each serum, the representative Shigella strains showed the same ranking of susceptibility as had been found with the pooled sera (Fig. 3). Although some of the sera killed even S. sonnei M23 efficiently at a concentration of $10 \%$, at lower concentrations they showed similar bactericidal activity to that of the pooled normal human serum. 


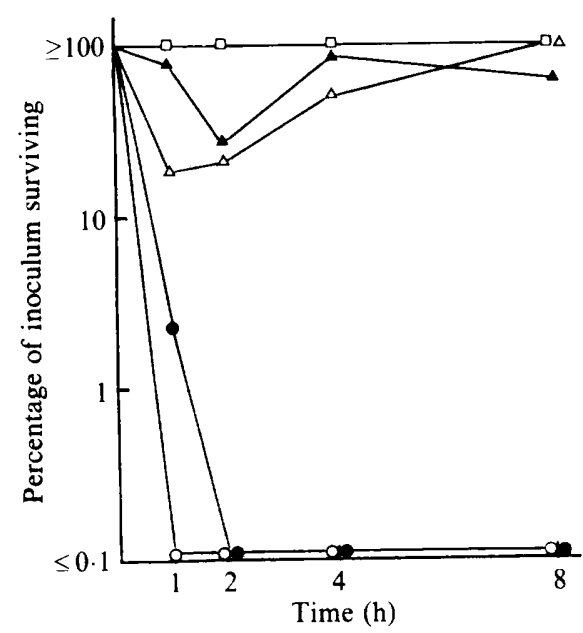

Fig. 1

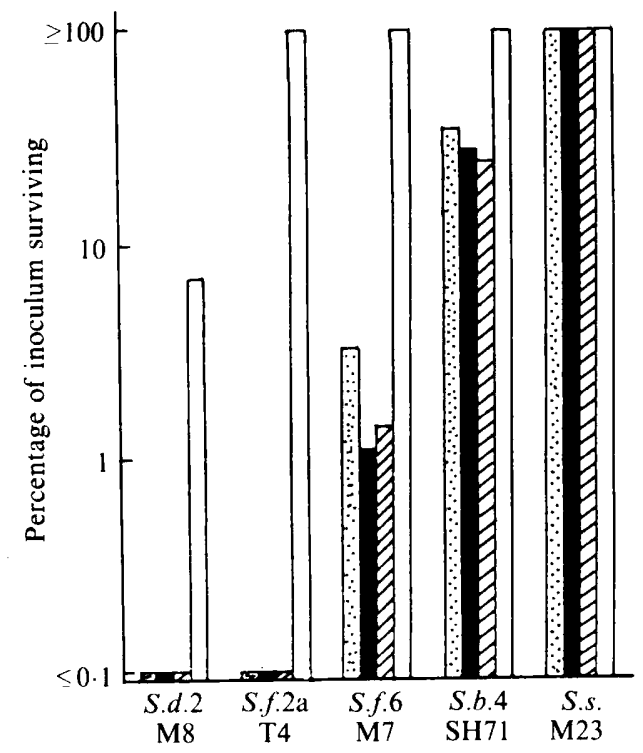

Fig. 2

Fig. 1. Kinetics of killing of Shigella spp. (initial cell density about $10^{6}$ bacteria $\mathrm{ml}^{-1}$ ) by $10 \%$ pooled normal human serum in tryptone/glucose broth. $S$. dysenteriae $2 \mathrm{M} 8 ; 0, S$. flexneri $2 \mathrm{a} \mathrm{T} 4 ; \Delta, S$. flexneri $6 \mathrm{M} 7 ; \triangle, S$. boydii $4 \mathrm{SH} 71 ; \square, S$. sonnei $\mathrm{M} 23$.

Fig. 2. Kinetics of killing of $S$. dysenteriae $2 \mathrm{M} 8$, S. flexneri $2 \mathrm{a} \mathrm{T} 4$, S. flexneri $6 \mathrm{M} 7$, S. boydii $4 \mathrm{SH} 71$ and $S$. sonnei M23 by $10 \%$ human serum with various bacterial inocula $\left(\square, 10^{5} ; \square, 10^{6} ; \square, 10^{7}\right.$; $\square, 10^{8}$ organisms $\mathrm{ml}^{-1}$ ).

Table 1. Susceptibility of Shigella strains to various concentrations of normal human serum

The results are shown as number of 'resistant' strains/number of strains tested. Viability of more than $10^{-1}$ of the inoculum at $4 \mathrm{~h}$ post-inoculation was considered resistant.

\begin{tabular}{lccccc} 
& \multicolumn{5}{c}{ Serum concn (\%) } \\
\cline { 2 - 6 } \multicolumn{1}{c}{ Species* } & 5 & 10 & 20 & 40 & 80 \\
S. dysenteriae & $1 / 7$ & $0 / 11$ & ND & ND & ND \\
S. flexneri serotypes $1-5$ & $1 / 16$ & $0 / 42$ & ND & ND & ND \\
S. flexneri serotype 6 & $10 / 10$ & $5 / 12$ & $0 / 12$ & ND & ND \\
S. boydii & $6 / 7$ & $6 / 7$ & $0 / 7$ & ND & ND \\
S. sonnei (form I) & ND & $15 / 15$ & $24 / 24$ & $7 / 24$ & $5 / 24$
\end{tabular}

ND, Not done.

* About $5 \times 10^{6}$ organisms $\mathrm{ml}^{-1}$ in the reaction mixture.

\section{Role of complement in bacterial killing}

Heat inactivation at $56{ }^{\circ} \mathrm{C}$ for 30 min completely destroyed the ability of human serum to kill Shigella. Serum heated at $50^{\circ} \mathrm{C}$ for $20 \mathrm{~min}$, which depletes it of alternative complement pathway activity, was as potent as untreated control serum in killing Shigella strains (Fig. 4). On the other hand, serum treated with MgEGTA, which selectively inhibits classical complement pathway activity, showed considerably less potency than untreated control serum (Fig. 5). In both cases, however, the test strains showed the same ranking with regard to serum susceptibility as before (Figs 4 and 5). 


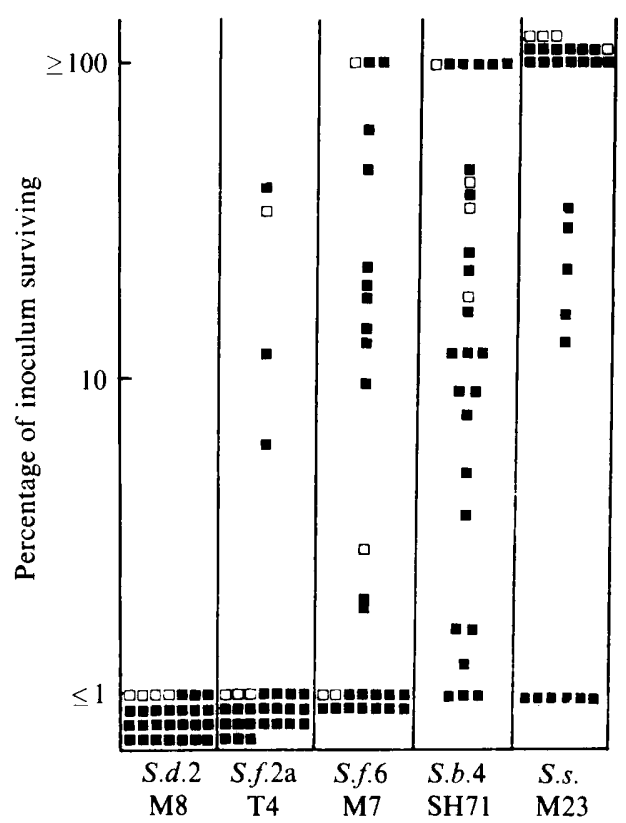

Fig. 3. Killing of $S$. dysenteriae $2 \mathrm{M} 8$, $S$. flexneri $2 \mathrm{a}$ T4, $S$. flexneri $6 \mathrm{M} 7, S$. boydii $4 \mathrm{SH} 71$ and $S$. sonnei M23 by normal human sera $(\square)$ and sera from dysentery patients $(\square)$. The initial cell density was about $10^{6}$ bacteria $\mathrm{ml}^{-1}$ in $10 \%$ serum.

(a)

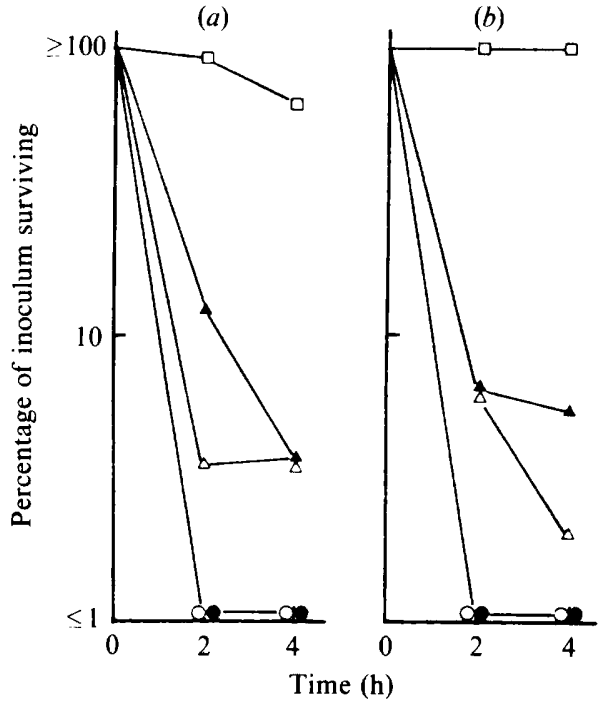

Fig. 4
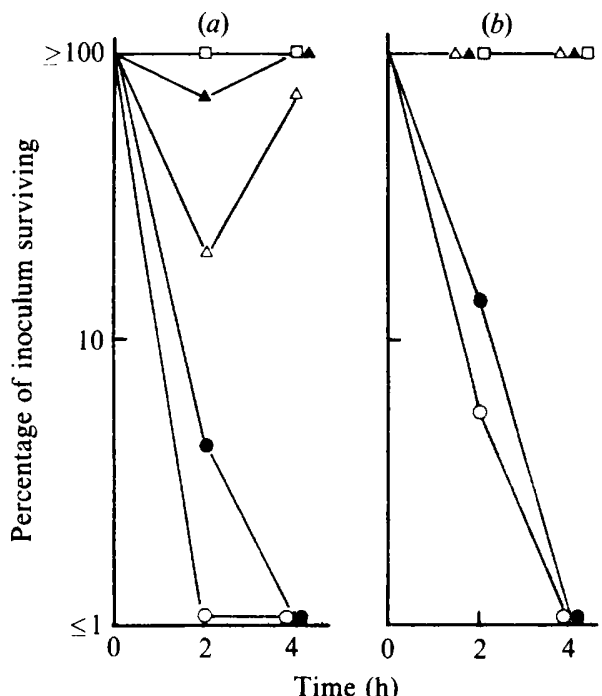

Fig. 5

Fig. 4. Role of the classical complement pathway in killing of Shigella. (a) $10 \%$ human serum in tryptone/glucose broth; $($ b $) 10 \%$ heat-treated $\left(50^{\circ} \mathrm{C}, 20 \mathrm{~min}\right)$ human serum.,$S$. dysenteriae $2 \mathrm{M8} ; \mathrm{O}$, $S$. flexneri $2 \mathrm{a} \mathrm{T} 4 ; \triangle, S$. flexneri $6 \mathrm{M} 7 ; \triangle, S$. boydii $4 \mathrm{SH} 71 ; \square, S$. sonnei $\mathrm{M} 23$. The initial cell density was about $10^{6}$ bacteria $\mathrm{ml}^{-1}$.

Fig. 5. Role of the alternative complement pathway in killing of Shigella $(a) 10 \%$ human serum in $\mathrm{GVB}^{2+}$; (b) $10 \%$ human serum in GBV with MgEGTA.,$S$. dysenteriae $2 \mathrm{M} 8$; O, S. flexneri $2 \mathrm{a}$ T4; $\triangle, S$. flexneri $6 \mathrm{M} 7 ; \triangle, S$. boydii $4 \mathrm{SH} 71 ; \square, S$. sonnei $\mathrm{M} 23$. The initial cell density was about $10^{6}$ bacteria $\mathrm{ml}^{-1}$. 


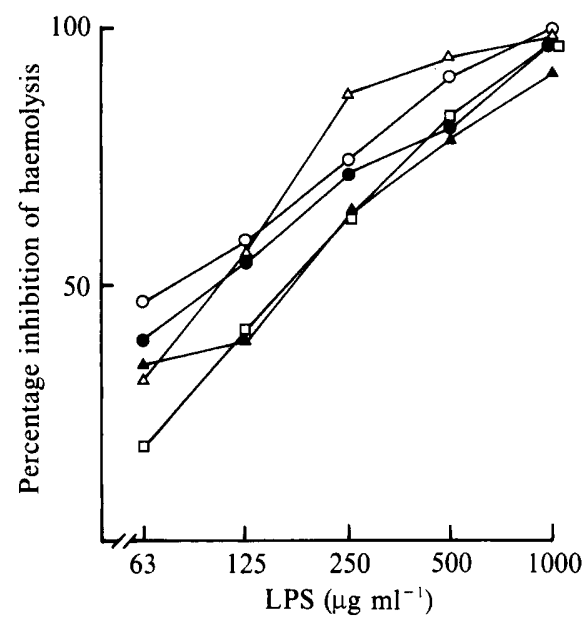

Fig. 6. Anticomplementary effect of LPS isolated from S. dysenteriae 2 M8 (O), S. flexneri 2a T4 (O), $S$. flexneri $6 \mathrm{M} 7(\Delta), S$. boydii $4 \mathrm{SH} 71(\triangle)$ and $S$. sonnei M23 $(\square)$.

Table 2. Inhibition of serum bactericidal activity against Shigella strains by homologous and heterologous LPS

The concentration of serum was $10 \%$ with strains $\mathrm{M} 8$ and $\mathrm{T} 4,20 \%$ with strain $\mathrm{M} 7$, and $30 \%$ with strain M23. The concentration of LPS was $200 \mu \mathrm{g} \mathrm{ml}^{-1}$ except where indicated.

\section{LPS from}

S. dysenteriae 2 M8
S. flexneri $2 \mathrm{a}$ T4
S. flexneri $6 \mathrm{M} 7$
S. boydii 4 SH71
S. sonnei (form I) M23

S. dysenteriae $2 \mathrm{M} 8$

S. sonnei (form I) M23

No LPS
Percentage survival of strains:

$\begin{array}{cccc}\text { M8 } & \text { T4 } & \text { M7 } & \text { M23 } \\ 210 & 0.2 & 2.3 & 27.5^{*} \\ 0.2 & 425 & 1 \cdot 1 & <0.1^{*} \\ 0.6 & 1.3 & 292 & 15.9^{*} \\ 0.5 & 2.9 & 2.8 & 0.7^{*} \\ 0.6 & 0.7 & 1.2 & 725^{*} \\ 0.3 & <0.1 & 0.5 & 1.2\end{array}$

* LPS concentration $100 \mu \mathrm{g} \mathrm{ml}^{-1}$.

\section{Anticomplementary activity of Shigella LPS}

The anticomplementary activity of LPS of the representative Shigella strains was measured to determine whether their different susceptibility to human serum was due to differences in the depletion of complement-mediated haemolytic activity by LPS. The anticomplementary properties of Shigella LPS in sheep-erythrocyte haemolytic assays (Shafer et al., 1984) was dose dependent, but there was no difference in depletion of complement-mediated haemolytic activity among the different Shigella LPS preparations (Fig. 6).

\section{Inhibition of serum bactericidal activity by Shigella LPS}

Table 2 shows the percentage survival of Shigella strains in pooled normal human serum treated with 100 or $200 \mu \mathrm{g} \mathrm{LPS} \mathrm{ml}{ }^{-1}$ from the representative Shigella strains. Under conditions where untreated serum killed most of the Shigella organisms, the strains survived well in serum preincubated with LPS obtained from the homologous strains, suggesting the involvement of specific immunoglobulins in serum killing of Shigella. 


\section{DISCUSSION}

Kinetic studies with normal human serum showed that the lower the inoculum of bacteria and/or the higher the concentration of serum, the more susceptible were the Shigella strains to killing (Figs 1 and 2, Table 1). The Shigella spp. differed in susceptibility to human serum: $S$. dysenteriae and $S$. flexneri serotypes 1-5 were the most susceptible, $S$. flexneri serotype 6 and $S$. boydii were intermediate, and $S$. sonnei was the least susceptible. Electron microscopy showed that the Shigella strains were not only killed but also lysed by human serum (data not shown).

Susceptibility of a number of Gram-negative bacteria to the bactericidal activity of immune or nonimmune sera has been attributed to their LPS composition (Taylor, 1983; Shafer et al., 1984; Schiller et al., 1984). Our results also suggested that the variation in susceptibility could be due to $\mathrm{O}$ antigens of Shigella LPS. It is not surprising that $S$. flexneri 6 strains differed from other $S$. flexneri serotypes in susceptibility to human serum, since the LPS structures of the two groups are quite different (Lindberg, 1979). It is unlikely that other cell-surface components such as capsular antigens, pili or plasmid-encoded outer-membrane proteins are responsible for the differences in serum susceptibility, because the differences in susceptibility we observed correlated with serological differences in $\mathrm{O}$ antigens of LPS. We found no relationship between serum susceptibility and the presence of antibiotic-resistance plasmids or large plasmids responsible for invasiveness (unpublished observations).

The bactericidal effects of immune or nonimmune serum are mediated by activated components of the classical or alternative complement pathway (Taylor, 1983; Götze \& MüllerEberhard, 1971). Activation of either pathway can lead to membrane damage resulting in cell death (Taylor, 1983). Our study of the mechanism of complement activation by Shigella strains indicated that both classical and alternative pathways were involved in serum killing of Shigella organisms, but that the classical pathway was more important (Figs 4 and 5). In either case, however, the species showed the same ranking with respect to serum susceptibility. Other Gram-negative bacteria such as Haemophilus influenzae (Quinn et al., 1977), Salmonella spp. (Joiner et al., 1982), Campylobacter spp. (Blaser et al., 1985), and Escherichia coli (Taylor \& Parton, 1977) are known to activate both complement pathways, but Neisseria gonorrhoeae (Shafer et al., 1984), Pseudomonas aeruginosa (Schiller et al., 1984) and Haemophilus ducreyi (Odumeru et al., 1985) activate mainly the classical pathway. •

We then asked whether the differences in susceptibility to normal human serum among Shigella spp. result from differential activation of human complement by different LPS, or whether differences in the LPS structure itself are responsible, by determining susceptibility to the membrane attack complex of human complement. The fact that we found no difference in depletion of complement-mediated haemolytic activity among different Shigella LPS preparations (Fig. 6) supports the latter possibility.

Although there were great variations among normal individual sera and sera from dysentery patients in antibody titre against Shigella LPS as assessed by enzyme-linked immunosorbent assay (unpublished observation), these sera showed similar bactericidal activity against Shigella spp. to that of the pooled normal human serum. On the other hand, treatment of human serum with Shigella LPS inhibited its bactericidal activity against homologous strains under conditions where untreated serum killed most of the Shigella strains. The results might suggest that antibodies in only minute amounts were sufficient for killing Shigella strains through the classical complement pathway, as also reported by Reed \& Albright (1974). Natural antibodies directed against the surface antigens of a number of Gram-negative bacteria have also been demonstrated in nonimmune serum (Schoolnik et al., 1976; Schwab \& Reeves, 1966; Skarnes, 1978).

Reed \& Albright (1974) reported that most $S$. flexneri 1 and $S$. sonnei strains are sensitive to serum, most $S$. flexneri 2 strains are intermediate, and all $S$. flexneri 3 strains tested are resistant, but there is also wide variation within some of the serogroups. They also reported that both classical and alternative complement pathways are responsible for the killing (Reed \& Albright, 1974). Our findings on susceptibility of Shigella to human serum differ from theirs, possibly due to the different bactericidal assay systems: they used stationary-phase bacteria and gel Hanks' 
solution, while we used exponential-phase bacteria, and, in most of the experiments, tryptone/glucose broth.

The possible role of serum killing of Shigella in curing or preventing shigellosis is still unclear. Shigellosis is only a minimally invasive disease, and these serum complement components may have little opportunity to come in contact with the disease-producing organisms, since complement is scarce in intestinal epithelial tissues. However, during the most extensive stage of the disease process acute massive inflammation takes place, resulting in ulceration of epithelial tissues and passage of blood and exudates in the stools, so serum complement components could well interact with invading organisms. Shigellosis is a localized enteric infection and, for unknown reasons, Shigella bacteraemia is very rare (Keusch, 1979). Nonetheless, episodes of Shigella bacteraemia have been reported in the literature (Hallet \& Scragg, 1978; Koshi et al., 1979; Struelens et al., 1985; Martin et al., 1983). There is controversy over which Shigella spp. are most liable to cause bacteraemia. Struelens et al. (1985) demonstrated a significantly higher frequency of Shigella bacteraemia with $S$. dysenteriae 1 as opposed to other serotypes in Bangladesh, whereas in other reports (Hallet \& Scragg, 1978; Koshi et al., 1979; Martin et al., $1983)$ there is no evidence suggesting any preponderance of one species over the others as a causative agent of Shigella bacteraemia. Still epidemiologically unexplained also is the change in species prevalence in which $S$. sonnei has emerged as the most common isolate, especially in the industrialized countries (Blaser et al., 1983; Parker, 1984). Our results may contribute to explaining such unsolved questions. They may also serve as a basis for the development of Shigella vaccines.

We thank T. Chida for his excellent technical assistance, and Y. Kudo and H. Watanabe for providing S. boydii and $S$. dysenteriae 1 strains.

This work was supported by a Grant-in-aid for Scientific Research (no. 61570223) from the Ministry of Education, Science, and Culture, and in part by the US-Japan Medical Science Program Cholera Panel.

\section{REFERENCES}

Blaser, M. J., Pollard, R. A. \& Feldman, R. A. (1983). Shigella infections in the United States, 1974-1980. Journal of Infectious Diseases 147, 771775.

Blaser, M. J., Smith, P. F. \& Kohler, P. F. (1985). Susceptibility of Campylobacter isolates to the bactericidal activity of human serum. Journal of Infectious Diseases 151, 227-235.

DuPont, H. L. \& Pickering, L. K. (1980). Infections of the Gastrointestinal Tract. Microbiology, Pathophysiology, and Clinical Features. New York: Plenum.

Fine, D. P., Marney, S. M., JR, Colley, D. G., Sergent, J. S. \& DesPrez, R. M. (1972). C3 shunt activation in human serum chelated with EGTA. Journal of Immunology 109, 807-809.

Götze, O. \& MÜller-Eberhard, H. J. (1971). The C3-activator system: an alternative pathway of complement activation. Journal of Experimental Medicine 134 (supplement), 90-108.

Hallet, A. F. \& SCRaGG, J. N. (1978). Shigella bacteraemia in Africans. Transactions of the Royal Society of Tropical Medicine and Hygiene 72, 673-674.

JoINer, K. A., Hammer, C. H., Brown, E. J., Cole, R. J. \& Frank, M. M. (1982). Studies on the mechanism of bacterial resistance to complementmediated killing. I. Terminal complement components are deposited and released from Salmonella minnesota S218 without causing bacterial death. Journal of Experimental Medicine 155, 797-808.

Keusch, G. T. (1979). Shigella infections. Clinics in Gastroenterology 8, 645-662.

Koshi, G., Daniel, J. \& Pereira, S. M. (1979). Septicaemic manifestations of shigellosis. Indian Journal of Medical Research 70, 916-922.

LaBrec, E. H., Schneider, H., Magnani, T. J. \& FormaL, S. B. (1964). Epithelial cell penetration as an essential step in the pathogenesis of bacillary dysentery. Journal of Bacteriology 88, 1503-1518.

LINDBERG, B. (1979). Structural studies on lipopolysaccharide. In Microbiology - 1979, pp. 172-175. Edited by D. Schlessinger. Washington, DC: American Society for Microbiology.

Lowell, G., MacDermott, R., Summers, P., ReEder, A., Bertovich, M. \& Formal, S. B. (1980). Antibody-dependent cell-mediated antibacterial activity: K lymphocytes, monocytes, and granulocytes are effective against Shigella. Journal of Immunology 125, 2778-2784.

Martin, T. B., Habbick, F. \& NysSen, J. (1983). Shigellosis with bacteremia: a report of two cases and a review of the literature. Pediatric Infectious Disease 2, 21-26.

MAYER, M. M. (1961). Complement and complement fixation. In Experimental Immunochemistry, pp. 133240. Edited by E. A. Kabat \& M. M. Mayer. Springfield: Charles C. Thomas.

Moll, A., Cabello, F. \& Timmis, K. (1979). Rapid assay for the determination of bacterial resistance to the lethal activity of serum. FEMS Microbiology Letters 6, 273-276.

Morgan, D. R., DuPont, H. L., Gonik, B. \& KoHL, S. (1984a). Cytotoxicity of human peripheral blood 
and colostral leukocytes against Shigella species. Infection and Immunity 46, 25-33.

Morgan, D. R., DuPont, H. L., Wood, L. V. \& KoHL, S. $(1984 b)$. Cytotoxicity of leukocytes from normal and Shigella-susceptible (opium-treated) guinea pigs against virulent Shigella sonnei. Infection and Immunity 46, 22-24.

Odumeru, J. A., Wiseman, G. M. \& Ronald, A. R. (1985). Role of lipopolysaccharide and complement in susceptibility of Haemophilus ducreyi to human serum. Infection and Immunity 50, 495-499.

Ogawa, H., Nakamura, A., Nakaya, R., Mise, K., Honjo, S., Takasaka, M., Fujiwara, T. \& ImaIzUMI, K. (1967). Virulence and epithelial cell invasiveness of dysentery bacilli. Japanese Journal of Medical Science and Biology 20, 315-328.

Okamura, N., Nagai, T., Nakaya, R., Kondo, S., Murakami, M. \& Hisatsune, K. (1983). HeLa cell invasiveness and $\mathrm{O}$ antigen of Shigella flexneri as separate and prerequisite attributes of virulence to evoke keratoconjunctivitis in guinea pigs. Infection and Immunity 39, 505-513.

PARKer, M. T. (1984). Bacillary dysentery. In Topley and Wilson's Principles of Bacteriology, Virology and Immunity, vol. 3, Bacterial Diseases, pp. 434-445. Edited by G. S. Wilson, A. A. Miles \& M. T. Parker. London: Edward Arnold.

Quinn, P. H., Crosson, F. J., JR, Winkelstein, A. \& MoAXon, E. R. (1977). Activation of the alternative complement pathway by Haemophilus influenzae type b. Infection and Immunity 16, 400-402.

REED, W. P. (1975). Serum factors capable of opsonizing Shigella for phagocytosis by polymorphonuclear neutrophils. Immunology 28, 1051-1059.

REED, W. P. \& Albright, E. L. (1974). Serum factors responsible for killing of Shigella. Immunology 26, 205-215.

Schiller, N. L., Alazard, M. J. \& Borowski, R. S. (1984). Serum sensitivity of a Pseudomonas aerugin- osa mucoid strain. Infection and Immunity 45, 748755

SChoolnik, G. K., Buchanan, T. M. \& Holmes, K. K. (1976). Gonococci causing disseminated infection are resistant to the bactericidal action of normal serum. Journal of Clinical Investigation 58, 11631173.

Schwab, G. E. \& ReEves, P. R. (1966). Comparison of the bactericidal activity of different vertebrate sera. Journal of Bacteriology 91, 106-112.

Shafer, W. M., JoIner, K., Guymon, F., Cohen, M. S. \& SPARLING, P. F. (1984). Serum sensitivity of Neisseria gonorrhoeae: the role of lipopolysaccharide. Journal of Infectious Diseases 149, 175-183.

SKARNES, R. C. (1978). Humoral bactericidal systems: nonspecific and specific mechanisms. Infection and Immunity 19, 515-522.

Stoll, B. J, Glass, R. I., HuQ, M. I., Khan, M., Banu, H. \& HolT, J. (1982). Epidemiologic and clinical features of patients infected with Shigella who attended a diarrheal disease hospital in Bangladesh. Journal of Infectious Diseases 146, 177-183.

Struelens, M. J., Patte, D., Kabir, I., Salam, A., NATH, S. K. \& Butler, T. (1985). Shigella septicemia: prevalence, presentation, risk factors, and outcome. Journal of Infectious Diseases 152, 784-790.

TAYLOR, P. W. (1983). Bactericidal and bacteriolytic activity of serum against gram-negative bacteria. Microbiological Reviews 47, 46-83.

TAYLOR, P. W. \& PARTON, R. (1977). A protein factor associated with serum resistance in Escherichia coli. Journal of Medical Microbiology 10, 225-232.

Wardlaw, A. C. \& Pillemer, L. (1956). The properdin system and immunity. V. The bactericidal activity of the properdin system. Journal of Experimental Medicine 103, 553-575.

WestPhal, O., LÜDERITZ, O. \& Bister, R. (1952). Über die Extraktion von Bakterien mit Phenol/ Wasser. Zeitschrift für Naturforschung 7b, 148-155. 